\title{
UBÓSTWO INSTYTUTU ZAKONNEGO W RELACJI DO ZAGADNIENIA DÓBR KOŚCIELNYCH
}

Treść: Wstęp. - 1. Świadectwo ubóstwa instytutu zakonnego. - 2. Zarząd dobrami instytutu zakonnego. - 2.1. Ekonom w instytucie zakonnym. - 2.2. Administracja nadzwyczajna, alienacja, długi i zobowiązania. - 3. Dobra kościelne. - Podsumowanie: instytut a dobra kościelne.

\section{Wstęp}

Instytuty zakonne, w których osoby całkowicie poświęcają się Bogu, są szczególnym znakiem wiary dla całego świata ${ }^{1}$. Zawiera się w tym publiczne świadectwo zakonników dane Chrystusowi i Kościołowi ${ }^{2}$. Jest to także świadectwo całego instytutu o wartościach życia zakonnego, którego częścią jest ubóstwo. Świadectwo to wskazuje, że przede wszystkim Bóg jest prawdziwym bogactwem życia ludzkiego. „Dlatego właśnie ewangeliczne ubóstwo przeciwstawia się z całą mocą bałwochwalczemu kultowi mamony i staje się proroczym wezwaniem skierowanym do społeczeństwa, które żyjąc W wielu częściach świata $\mathrm{w}$ dobrobycie, jest wystawione na niebez-

\footnotetext{
1 ,Życie zakonne, jako poświęcenie całej osoby, ukazuje przedziwne zaślubiny w Kościele dokonane przez Boga, stanowiące znak przyszłego wieku. Dzięki temu osoba zakonna dokonuje całkowitego oddania się, jakby złożenia się Bogu w ofierze, na skutek czego całe jej istnienie staje się ustawiczną czcią Boga w miłości”, Codex Iuris Canonici, auctoritate Joannis Pauli PP. promulgatus, Kodeks Prawa Kanonicznego. Przekład polski zatwierdzony przez Konferencję Episkopatu, 25.01.1983, Poznań 1984 (dalej KPK 1983), kan. 607 §1.

2 Por. tamże, kan. 607 §3.
} 
pieczeństwo utraty poczucia umiaru i świadomości istotnej wartości rzeczy"3.

Ubóstwo w instytutach zakonnych posiada wymiar indywidualny, ale także wspólnotowy. O wspomnianym wyżej proroczym wezwaniu świadczy również cały instytut. W opracowaniu poniższym zostaną przywołane wspólnotowe aspekty ślubu ubóstwa, będące świadectwem życia zakonnego. W dalszej kolejności zostaną omówione kwestie zarządu dobrami doczesnymi, które najczęściej podejmują ekonomowie zakonni i przełożeni. Również zostaną podjęte takie zagadnienia, jak: administracja nadzwyczajna, alienacja, długi i zobowiązania. Następnie zostanie przywołane jedno z zagadnień, które jest związane z dobrami doczesnymi Kościoła, tj. pojęcie dóbr kościelnych. Końcowe rozważanie zmierzy się z pytaniem, jaka jest relacja ślubu ubóstwa, w jego wspólnotowym ujęciu do dóbr kościelnych oraz czy wymagania ubóstwa, będące udziałem całego instytutu, łączą się z zagadnieniem dóbr kościelnych, czy też nie.

\section{1. Świadectwo ubóstwa instytutu zakonnego}

Zakonnicy składając ślub ubóstwa naśladują Chrystusa ubogiego. Wybierając życie zakonne, godzą się tym samym na zależność od przełożonych, również w zakresie wszelkich dóbr materialnych. Wspólna dla wszystkich instytutów zakonnych norma stanowi: „Ewangeliczna rada ubóstwa do naśladowania Chrystusa, który będąc bogaty stał się dla nas cierpiącym niedostatek, prócz życia w rzeczywistości i w duchu ubogiego, prowadzonego pracowicie w trzeźwości i dalekiego od ziemskich bogactw, niesie ze sobą zależność i ograniczenie w używaniu dóbr i dysponowaniu nimi, zgodnie z własnym prawem poszczególnych instytutów"4.

3 JAN PAWEe II, Posynodalna adhortacja apostolska o życiu konsekrowanym i jego misji w Kościele i w świecie ,Vita consecrata”, 25.03.1996, Ząbki 1996, nr 90.

${ }^{4}$ KPK 1983, kan. 600; por. Y. SUGAWARA, La povertà evangelica nel Codice: norma comune (c. 600) e applicazione individuale (c. 668), Periodica 89(2000), z. 1, s. 45-77. Duchowe i teologiczne znaczenie ubóstwa, por. E. GAMBARI, Życie zakonne po Soborze Watykańskim II, tłum. J. E. Bielecki, Kraków 1998, s. 342-348. 
W zrozumieniu, czym jest ubóstwo zakonne w aktualnym kontekście życia, warto sięgnąć do jednego z dokumentów Soboru Watykańskiego II, jakim jest dekret Perfectae caritatis. Wynika z niego, że wraz z zasadami określającymi omawiany ślub, np. w konkretnym instytucie zakonnym, należy akcentować także jego duchowy wymiar. Treść wyżej wymienionego dekretu podkreśla, że ,zakonnicy winni być ubogimi i w duchu, i w rzeczywistości”s. Duchowe interpretowanie ślubu ubóstwa przez każdego z nich z osobna, wzmacnia życie braterskie całej wspólnoty zakonnej ${ }^{6}$.

Myśl dokumentu soborowego zauważa następnie zbiorowe świadectwo ubóstwa, które jest nakierowane na potrzeby Kościoła i pomoc ubogim ${ }^{7}$. „Chociaż instytuty, zachowując swoje reguły i konstytucje, mają prawo posiadania tego wszystkiego, co niezbędne do utrzymania i do prowadzenia ich dzieł, to jednak niech unikają wszelkiej postaci zbytku, nieumiarkowanego zysku i gromadzenia majątku"s. Ewangeliczne ubóstwo jest nie tylko służbą ubogim, ale także wartością samą w sobie, które pokazuje, że Bóg jest prawdziwym bogactwem człowieka ${ }^{9}$. Umiłowanie ubogich oraz promocja sprawiedliwości domaga się odpowiednich rozwiązań, także na poziomie całego instytutu i jego prawa własnego. „Powinno to skłonić każdy Instytut, zgodnie z jego specyficznym charyzmatem, do przyjęcia skromnego i surowego stylu życia - zarówno indywidualnego, jak i wspólnotowego"10.

${ }^{5}$ Dekret Soboru Watykańskiego II o przystosowanej do współczesności odnowie życia zakonnego Perfectae caritatis, 28.10.1965, w: Sobór Watykański II, Konstytucje, Dekrety, Deklaracje, Poznań 2002, s. 264-275, nr 13.

${ }^{6}$ „Natomiast ubóstwo $w$ duchu, pokora, prostota, umiejętność uznania darów innych, cenienie takich wartości ewangelicznych, jak życie ukryte z Chrystusem w Bogu, szacunek dla ukrytej ofiary, dowartościowanie najuboższych, bezinteresowna służba sprawom nie przynoszącym dochodu ani rozgłosu, to elementy jednoczące wspólnotę braterską mocą ślubu ubóstwa”, KongRegacja Instytutów ŻyCia KonsEKROWANEGO I Stowarzyszeń Życia Apostolskiego, Życie braterskie we wspólnocie „, Congregavit nos in unum Christi amor”, 02.02.1994, Ząbki 1994, nr 44.

7 Por. Perfectae caritatis, nr 13.

8 Tamże.

9 Por. Vita consecrata, nr 90; A. Chrapkowski, Zarządzanie dobrami doczesnymi w instytutach zakonnych, Annales Canonici 3(2007), s. 143-144.

${ }^{10}$ Vita consecrata, $\mathrm{nr} 82$. 
Prawo powszechne Kościoła przenosi myśl Magisterium na zapis normy prawnej. Powyżej przywołaną myśl o zbiorowym świadectwie ubóstwa i pomocy ubogim wyraża treść kan. 640: „Uwzględniając miejscową sytuację, instytuty powinny starać się dawać niejako zbiorowe świadectwo miłości i ubóstwa, oraz stosownie do możliwości przeznaczać część własnych dóbr na potrzeby Kościoła, jak również pomóc w utrzymaniu osób potrzebujących"11. W ten sposób prawodawca kościelny ujął wskazania trzynastego numeru soborowego dekretu Perfectae caritatis. Jest to wyraźne zalecenie, rekomendacja, czy polecenie zaangażowania się w zbiorowe świadectwo miłości i ubóstwa $^{12}$. Zaangażowanie powyższe powinno korelować z sytuacją lokalną, tj. z warunkami środowiska, w którym żyją: wspólnota zakonna oraz osoby potrzebujące pomocy ${ }^{13}$. Poziom życia społeczeństwa jest wskaźnikiem dla zakonników, na jakim poziomie ich życie jest lub nie jest świadectwem. Kanon 640 stanowi jakby „duch prawa”, czy wskazanie kierunku, w jakim powinno rozwijać się własne prawodawstwo i dyskusja nad tą problematyką. Chodzi też o realne zaangażowanie instytutów, o przeznaczanie części własnych dóbr na potrzeby Kościoła i biednych. Niekoniecznie są to tylko potrzeby bytowe i materialne. Pomoc, która nie jest przekazaniem tzw. dóbr zbywających, zauważa także szereg innych potrzeb ludzkich ${ }^{14}$; w tym potrzeby osób, które są

${ }^{11}$ KPK 1983, kan. 640; por. Y. SugaWARA, La povertà evangelica nel Codice: applicazione colletiva (cann. 634-640), Periodica 89(2000) z. 2, s. 277-283; V. MoscA, Povertà e amministrazione dei beni negli Istituti religiosi, Quaderni di Diritto Ecclesiale 2(1990), s. 252-253. Instytuty zakonne niosą świadectwo miłości i służą ubogim, por. Kongregacja Instytutów Życia Konsekrowanego i Stowarzyszeń Życia ApostolskieGO, Rozpocząć na nowo od Chrystusa. Odnowione zaangażowanie życia konsekrowanego $w$ trzecim tysiacleciu Ripartire da Christo, 19.05.2002, Poznań 2002, nr 33-36.

${ }^{12}$ Por. A. Chrapkowski, Zarządzanie dobrami doczesnymi w instytutach zakonnych, s. 146.

${ }^{13}$ Por. tamże, s. 147; A. Chrapkowski, J. Krzywda, J. Wroceński, B. W. Zubert, Komentarz do Kodeksu Prawa Kanonicznego, t. II/2, red. J. Krukowski, Poznań 2006, s. 73.

${ }^{14}$ Por. B. W. Zubert, Komentarz do Kodeksu Prawa Kanonicznego. Księga II Lud Boży. Część III Instytuty życia konsekrowanego i stowarzyszenia życia apostolskiego, Lublin 1990, s. 111-112; E. GAMBARI, Życie zakonne po Soborze Watykańskim II, s. 374. 
uciekinierami, emigrantami, bezrobotnymi, uzależnionymi od różnych środków, itd. ${ }^{15}$

Wcześniej zarysowane wskazania Magisterium dla instytutów zakonnych zostały następnie wyrażone w kanonie 634: „Powinny jednak unikać wszelkiego luksusu, nadmiernego zysku i gromadzenia dóbr"16. Skromnego stylu życia zakonnego nie można pogodzić ze zbytkiem czy luksusem, co także nie jest do zaakceptowania z ogólnie rozumianym chrześcijańskim stylem życia. Przeciwnością dla życia zakonnego byłyby następnie zachowania cechujące się skąpstwem, chciwością czy nawet lichwą. Administracja dobrami zakonnymi musi być gospodarna, ale wyłączne gromadzenie dóbr nie jest ich celem. Dobra doczesne służą realizacji określonej misji kościelnej i własnego charyzmatu zakonnego.

Powyższe wskazania dotyczą wspólnoty zakonnej. Trzeba jednak oddzielić istnienie i administrację dobrami doczesnymi wspólnoty od dzieł apostolskich, które ona prowadzi ${ }^{17}$. Dzieła te wymagają nakładów materialnych stosownie do własnego celu, jak również dostosowania do wymogów prawodawstwa państwowego, np. szpitale, szkoły katolickie czy uczelnie wyższe.

W soborowym dokumencie Perfectae caritatis stwierdzono, że instytuty zakonne mają prawo posiadania tego wszystkiego, co niezbędne do ich utrzymania oraz do prowadzenia dzieł apostolskich. Tę myśl oddaje odpowiednia norma z Kodeksu Prawa Kanonicznego z 1983 r.: „Instytuty, prowincje i domy zakonne, jako osoby prawne na mocy samego prawa, zdolne są do nabywania, posiadania i alienowania dóbr doczesnych, chyba że konstytucje tę zdolność wykluczają lub ograniczają"18. Wymienione struktury są jednocześnie osobami prawnymi

${ }^{15}$ Por. Y. Sugawara, La povertà evangelica nel Codice: applicazione colletiva (cann. 634-640), s. 282-283.

${ }^{16}$ KPK 1983, kan. 634 §2. Styl życia ubogiego dotyczy ilości i jakości dóbr oraz rozciąga się na różne rzeczy, m.in. środki transportu, wygląd domu, itd., por. Y. SugAWARA, La povertà evangelica nel Codice: applicazione colletiva (cann. 634-640), s. 272.

${ }^{17}$ Por. A. ChrapKowski, Zarządzanie dobrami doczesnymi w instytutach zakonnych, S. 146.

${ }^{18}$ KPK 1983, kan. $634 \S 1$. Jest to norma analogiczna do kan. $1254 \S 1$, gdzie te 
publicznymi. Dobra doczesne zakonne podlegają prawu powszechnemu Kościoła, które zawiera przede wszystkim księga piąta Kodeksu z 1983 r.: „Dobra doczesne instytutów zakonnych jako kościelne rządzą się przepisami księgi V Dobra doczesne Kościoła, chyba że co innego wyraźnie zastrzeżono"19.

Prawo własności należy do tej osoby prawnej zakonnej, która je nabyła zgodnie z prawem ${ }^{20}$. W konsekwencji dobra należące do określonego instytutu, choćby był na prawie diecezjalnym, należą do instytutu, a nie do Kościoła partykularnego ${ }^{21}$.

Szczegółowe normy prawa własnego powinny regulować kwestie nabywania, posiadania i administracji dobrami doczesnymi. W ten indywidualny sposób każdy instytut wyraża i strzeże ubóstwa oraz daje o nim świadectwo: „Każdy jednak instytut powinien ustanowić odpowiednie normy, dotyczące używania i zarządu dóbr, które by stały na straży właściwego instytutowi ubóstwa, strzegły go i wyrażały"22. Normy własne regulują m.in. wewnętrzną strukturę instytutu, która może być bardzo złożona (wice-prowincje, delegatury, regiony, itd.). Prawo własne powinno określić, tak status prawny tych struktur, jak i kwestie

same prawa przysługują Kościołowi katolickiemu, por. tamże. Indywidualny aspekt ubóstwa zakonnika, por. tamże, kan. 668 §1-5.

${ }^{19}$ Tamże, kan. $635 \S 1$.

${ }^{20}$ Por. tamże, kan. 1256.

${ }^{21}$ Por. A. Chrapkowski, Zarzadzanie dobrami doczesnymi w instytutach zakonnych, s. 137. Instytuty zakonne często prowadzą dzieła diecezjalne, np. tzw. parafie zakonne. W takiej sytuacji należy w stosownych umowach rozgraniczyć stan posiadania parafii i domu zakonnego, własność dóbr nabywanych w przyszłości, sytuacje lokalowe, dochody, wydatki i finansowanie dzieła zakonnego i diecezjalnego, por. T. GAŁKowski, Zależności ekonomiczne pomiędzy Kościołem partykularnym a instytutami życia konsekrowanego, Prawo Kanoniczne 44(2001) nr 3-4, s. 78-86.

${ }^{22}$ KPK 1983, kan. 635 §2. Por. B. W. Zubert, Komentarz do Kodeksu Prawa Kanonicznego, s. 100-101; Y. SugaWARA, La povertà evangelica nel Codice: applicazione colletiva (cann. 634-640), s. 274-277; V. MoscA, Povertà e amministrazione dei beni negli Istituti religiosi, s. 242-244. Oprócz ogólnych zapisów dla całego instytutu w konstytucjach, zapisy na temat administracji mogą zawierać zbiory normatywne na poziomie prowincji czy wice-prowincji, por. A. ChrapKowsKi, J. KrZYWDA, J. WroceńSKi, B. W. Zubert, Komentarz do Kodeksu Prawa Kanonicznego, s. 67. 
nabywania, posiadania, administrowania i alienacji przezeń dóbr doczesnych $^{23}$.

Wyżej cytowany kan. 634 dopuszcza zapis, obowiązkowo ujęty w konstytucjach, który ogranicza zdolność nabywania i posiadania dóbr. Istnieją instytuty zakonne, które cechuje takie ograniczenie lub wykluczenie posiadania ${ }^{24}$. Ten stan rzeczy musi być opisany w konstytucjach instytutu, czy dotyczy całej tej osoby prawnej, jego części, czy niektórych aktów prawnych. Konsekwencją, przy braku zdolności posiadania, będzie przynależność dóbr kościelnych do Stolicy Apostolskiej lub innej osoby prawnej kościelnej.

\section{Zarząd dobrami instytutu zakonnego}

\subsection{Ekonom w instytucie zakonnym}

Zarząd dobrami zakonnymi domaga się zastosowania odpowiednich rozwiązań strukturalnych i personalnych. Jednym z ważniejszych elementów jest ustanowienie ekonomów. Rozwiązanie to występowało niemal od początku życia zakonnego, np. w klasztorach zorganizowanych według reguły św. Pachomiusza był ustanowiony ekonom klasztoru i ekonom federacji ${ }^{25}$. Aktualnie, prawo powszechne reguluje tę kwestię następująco: „W każdym instytucie, a także prowincji kierowanej przez wyższego przełożonego, powinien być ekonom, różny od wyższego przełożonego, a ustanowiony zgodnie $\mathrm{z}$ własnym prawem. Ma on zarządzać dobrami pod kierownictwem odnośnego przełożone-

${ }^{23}$ Por. A. ChrAPKOwSKI, Zarządzanie dobrami doczesnymi w instytutach zakonnych, s. $137-138$.

${ }^{24}$ Por. J. R. Bar, J. Kalowski, Prawo o instytutach, s. 90; E. Gambari, Życie zakonne po Soborze Watykańskim II, s. 369-370; A. CHrAPKOWsKI, Zarzadzanie dobrami doczesnymi w instytutach zakonnych, s. 138; V. MoscA, Povertà e amministrazione dei beni negli Istituti religiosi, s. 241; Y. SugaWARA, Le norme sui beni temporali negli istituti religiosi (can. 635), w: Iustitia in caritate, Miscellanea di studi in onore di Velasio de Paolis, Città del Vaticano 2005, s. 419-420.

${ }^{25}$ Por. B. W. Zubert, Komentarz do Kodeksu Prawa Kanonicznego, s. 101; J. R. BAR, J. Kalowski, Prawo o instytutach, s. 91. 
go. Również we wspólnotach lokalnych należy wedle możności ustanowić ekonoma, różnego od przełożonego miejscowego"26.

Uzasadnieniem dla takiej normy kodeksowej są m.in. względy praktyczne. W ramach życia wspólnotowego występuje podział zadań i funkcji, który może być rodzajem specjalizacji. Niektórzy zakonnicy posiadają umiejętności praktyczne oraz predyspozycje, a czasem i przygotowanie teoretyczne, do pełnienia funkcji administracyjnych. Odróżnienie zadań przełożonego od obowiązków ekonoma pozwala temu pierwszemu skupić się na animacji życia wspólnoty i odciąża od nadmiernej troski o rzeczy materialne ${ }^{27}$. Analogicznie w pierwotnym Kościele, diakoni troszczyli się o dobra doczesne, aby inni apostołowie i starsi gmin chrześcijańskich mogli oddać się „,modlitwie i posłudze słowa" ${ }^{28}$.

Prawo powszechne stanowi, że obowiązkowo należy ustanowić ekonoma dla całego instytutu oraz ekonoma prowincji. Do ekonoma generalnego należy administracja dobrami całego instytutu i nadzór nad wszelkimi działaniami ekonomicznymi struktur jemu podległych ${ }^{29}$. Szczegółowe kwestie dotyczące ustanowienia ekonoma powinno rozstrzygać prawo własne, w tym takie sprawy jak: wybór lub mianowanie oraz odwołanie z urzędu, długość kadencji, wymagane przymioty i kwalifikacje oraz zakres kompetencji ${ }^{30}$.

Również obowiązkowo należy ustanowić ekonoma prowincji. W jego kompetencjach zawiera się administracja dobrami wspólnymi prowincji i nadzór nad poszczególnymi domami zakonnymi. Urząd ekonoma prowincji występuje w tych instytutach, gdzie istnieje po-

${ }^{26}$ KPK 1983, kan. 636 §1; por. Y. SugawarA, La povertà evangelica nel Codice: applicazione colletiva (cann. 634-640), s. 283-288; V. DE PAOLIS, La rilevanza dell'economia nella vita religiosa, Angelicum 85(2008), s. 239-266.

${ }^{27}$ Por. B. W. Zubert, Komentarz do Kodeksu Prawa Kanonicznego, s. 101-102.

${ }^{28} \mathrm{Dz}$ 6, 1-6.

${ }^{29} \mathrm{O}$ zarządzie dóbr i obowiązkach administratorów, por. KPK 1983, kan. 12731289.

${ }^{30}$ Przykładowo, por. A. DomAszk, Funkcja ekonoma $w$ prawe własnym Towarzystwa św. Franciszka Salezego, Seminare. Poszukiwania Naukowe, 27(2010), s. 63-75. Por. także S. RECCHI, L'economo negli istituti religiosi, Quaderni di Diritto Ecclesiale 22(2009), s. 132-133, s. 135-137. 
dział na prowincje z odrębnym przełożonym wyższym ${ }^{31}$. Również prawo własne instytutu stanowi normy szczegółowe, które dotyczą ekonoma prowincji.

Nieco inna sytuacja może zaistnieć we wspólnocie lokalnej. Zasadniczo powinien być ustanowiony w niej ekonom różny od przełożonego. Konkretne możliwości i warunki określonej wspólnoty decydują o rozdzieleniu albo w wyjątkowej sytuacji połączeniu tych urzędów. Fakultatywne rozwiązanie zależy od trudności w ustanowieniu ekonoma lokalnego lub czasem niemożliwości, co wynika z przyczyn personalnych, czy z braku rzeczywistej potrzeby. Przez wspólnotę lokalną rozumie się przede wszystkim dom zakonny ${ }^{32}$, ale można odnieść tę normę kodeksową także do mniejszych struktur, które przynależą do określonego domu. W sytuacji, gdy z jakichś powodów nie można ustanowić ekonoma lokalnego, jego zadania wypełnia miejscowy przełożony ${ }^{33}$.

Według zapisu kan. 636 Kodeksu z 1983 r., ekonom wypełnia swe zadania pod zwierzchnictwem przełożonego. Na poziomie całego instytutu oraz prowincji, funkcje przełożonego i ekonoma są więc rozdzielne (inaczej są to urzędy niepołączalne), czyli pełnią je różne osoby $^{34}$. Jedynie we wspólnotach lokalnych, w razie konieczności, można dopuścić połączenie tych zadań. Ekonom jest zależny od przełożonych, tak w odniesieniu do zwyczajnego zarządu, jak i nadzwyczajnych czynności administracyjnych ${ }^{35}$.

Instytuty zakonne męskie dzieli się m.in. na kleryckie i niekleryckie $^{36}$. W kleryckich instytutach tym samym charyzmatem żyją duchowni oraz bracia zakonni. O ile nie istnieją szczególne zwyczaje w obrębie instytutu, to można powierzyć urząd ekonoma braciom

${ }^{31}$ Por. KPK 1983, kan. 621.

${ }^{32}$ Por. tamże, kan. 608.

${ }^{33}$ Por. B. W. Zubert, Komentarz do Kodeksu Prawa Kanonicznego, s. 103.

${ }^{34}$ Por. KPK 1983, kan. 152; A. Chrapkowski, J. Krzywda, J. Wroceński, B. W. ZuBerT, Komentarz do Kodeksu Prawa Kanonicznego, s. 68; S. ReCCHI, L'economo negli istituti religiosi, s. 133-134.

${ }^{35}$ Por. KPK 1983, kan. 638 §1-3.

${ }^{36}$ Por. tamże, kan. 588 §1-3. 
zakonnym odpowiednio przygotowanym do tych zadań. ,Zarząd dobrami doczesnymi nie jest bowiem funkcją ani specyficznie kapłańską, ani niezamienną i wobec braku sług ottarza i słowa desygnowanie na to stanowisko kapłanów rzadko będzie w tych instytutach celowe i zgodne z eklezjalnym pojmowaniem tego urzędu"37. Dyskusyjną natomiast sprawą jest powierzenie obowiązków ekonoma osobom, które nie są członkami konkretnego instytutu ${ }^{38}$.

Przed objęciem urzędu, ekonom powinien złożyć przysięgę, że swoje obowiązki będzie pełnić dobrze i sumiennie ${ }^{39}$. Do ekonoma, jako dobrego gospodarza, należy m.in.: zawieranie umów ubezpieczeniowych, pobieranie dochodów, spłacanie zobowiązań, prowadzenie ksiąg ekonomicznych, przestrzeganie wymaganych przepisów prawnych, w tym również prawa państwowego, przechowywanie dokumentacji, itd. ${ }^{40}$ Troska o instytut oraz pełnienie celów, jakie Kościół

${ }^{37}$ B. W. Zubert, Komentarz do Kodeksu Prawa Kanonicznego, s. 102.

${ }^{38}$ Por. A. Chrapkowski, Zarzadzanie dobrami doczesnymi w instytutach zakonnych, s. 141-142; L. Chiappetta, Il Codice di diritto canonico. Commento giuridico-pastorale, t. I, Roma 1996, s. 777; J. P. Schouppe, Elementi di diritto patrimoniale canonico, seconda edizione, Milano 2008, s. 207-208.

${ }^{39}$ Por. KPK 1983, kan. 1283 n. 1; przed objęciem urzędu należy sporządzić dokładny inwentarz dóbr, por. tamże, kan. 1283 n. 2-3.

${ }^{40}$ „Powinni zatem: $1^{\circ}$ czuwać, ażeby powierzone ich pieczy dobra nie przepadły lub nie doznały jakiejś szkody, zawierając w tym celu w razie potrzeby odpowiednie umowy ubezpieczające; $2^{\circ}$ troszczyć się, żeby własność dóbr kościelnych była zabezpieczona środkami ważnymi według prawa państwowego; $3^{\circ}$ przestrzegać przepisów zarówno prawa kanonicznego, jak i państwowego, albo wydanych przez fundatora, ofiarodawcę lub uprawnioną władzę, a zwłaszcza starać się, by Kościół nie poniósł szkody wskutek nieprzestrzegania ustaw państwowych; $4^{\circ}$ pobierać skrupulatnie i we właściwym czasie dochody z dóbr i należności, pobrane zaś przechowywać bezpiecznie i używać ich zgodnie z wolą fundatora albo z normami prawnymi; $5^{\circ}$ wypłacać w ustalonych terminach procenty, należne $\mathrm{z}$ tytułu pożyczki lub zastawu, czuwając nad odpowiednim zwrotem głównej sumy długu; $6^{\circ}$ pieniądze pozostałe po pokryciu wydatków, które mogą być korzystnie ulokowane, ulokować za zgodą ordynariusza na korzyść osoby prawnej; $7^{\circ}$ mieć należycie prowadzone księgi przychodów oraz rozchodów; $8^{\circ}$ pod koniec każdego roku sporządzić sprawozdanie z zarządu; $9^{\circ}$ dokumenty i dowody, na których opierają się prawa Kościoła lub instytucji do majątku, należycie porządkować i przechowywać w odpowiednim archiwum oraz strzec ich; autentyczne zaś ich odpisy, gdy się to da łatwo uczynić, złożyć w archiwum kurii.”, 
przed nim stawia domaga się gospodarności oraz starannego zarządzania dobrami kościelnymi. Wszelkie przeciwne działania, tj. różne formy niegospodarności, naruszają ślub ubóstwa, w tym przypadku administratorów ${ }^{41}$.

Jednym z głównych celów dóbr doczesnych Kościoła jest „,prowadzenie dzieł apostolatu i miłości, zwłaszcza wobec biednych"42. Jak już wyżej przedstawiono, każdy instytut ma dawać świadectwo ubóstwa, także przez pomoc udzielaną ubogim. Pomoc charytatywna może należeć do obowiązków ekonoma. Wówczas działalność dobroczynna zawiera się w ramach zwyczajnej administracji. Ekonom wspiera potrzebujących z posiadanych dóbr ruchomych, z zastrzeżeniem, że nie naruszy to podstaw ekonomicznych samej osoby prawnej ${ }^{43}$.

Wsparcia ekonomicznego potrzebują nie tylko osoby indywidualne, ale również całe struktury. Dotyczyć to może również poszczególnych części instytutu. W soborowym dekrecie Perfectae caritatis stwierdzono: „Prowincje i domy instytutów winny jedne drugim użyczać swoich dóbr doczesnych, tak aby te, które mają więcej, wspierały inne, które cierpią niedostatek"44. Szczegółowe sposoby rozwiązywania tych problemów normuje prawo własne. Również ekonom generalny czy prowincjalny może koordynować stosowną pomoc pomiędzy poszczególnymi strukturami wewnątrz instytutu. W obrębie instytutu

tamże, kan. 1284 §2. Tematykę zarządu dobrami doczesnymi, por. W. WóJcIK, J. KRUkowski, F. Lempa, Komentarz do Kodeksu Prawa Kanonicznego, t. 4, Lublin 1987, s. 66-84.

${ }^{41}$, ,Złe zarządzanie zakonnymi dobrami doczesnymi przez osoby do tego powołane ujemnie wpływa na współzainteresowanie i współodpowiedzialność pozostałych członków za sprawy materialne oraz stwarza niebezpieczeństwo poważnych nadużyć w przedmiocie ślubu ubóstwa oraz życia wspólnego.”, B. W. ZuBERT, Komentarz do Kodeksu Prawa Kanonicznego, s. 101.

${ }^{42}$ KPK 1983, kan. 1254 §2. Do ekonomów należy też zawieranie umów o pracę, w zgodzie z prawem państwowym i nauką społeczną Kościoła, por. tamże, kan. 1286.

${ }^{43}$ Por. tamże, kan. 1285. Por. E. GAMBARI, Życie zakonne po Soborze Watykańskim II, s. 685-686.

${ }^{44}$ Perfectae caritatis, nr 13. Por. A. ChrapKowski, Zarzadzanie dobrami doczesnymi w instytutach zakonnych, s. 147. 
może ponadto istnieć odrębny „fundusz solidarności”, którego celem jest pomoc szczególnie ubogim prowincjom lub domom zakonnym ${ }^{45}$.

Ekonom sprawuje swoje obowiązki pod kierownictwem przełożonego. Z tego stwierdzenia wynika kolejny obowiązek ekonoma, jednoznacznie artykułowany w prawie kodeksowym, tj. sprawozdawczość. „W czasie oraz w sposób określony we własnym prawie, ekonomi i inni zarządcy mają obowiązek przedłożyć kompetentnej władzy sprawozdanie z wykonanego zarządu"46.

Sprawozdania z wykonanego zarządu składa się przełożonym wewnętrznym. Niekiedy ekonoma, który jest członkiem instytutu, wspomagają ,inni zarządcy”. Chodzi o osoby zależne od ekonoma, które odpowiadają za określone sektory działalności apostolskiej (np. administracja szkoły, uczelni, wydawnictwa, szpitala). Tacy zarządcy zazwyczaj przedstawiają raporty ekonomowi, a ten z kolei składa je kompetentnej władzy, tj. przełożonemu osoby prawnej, której dobrami ekonom administruje. Do prawa własnego należy określenie zakresu sprawozdań, ich częstotliwości, itp. „Przedmiotem sprawozdań są według prawa własnego zazwyczaj nie tylko sprawy czysto materialne, lecz także wydatki związane z działalnością kulturalną, publicystyczną, gromadzeniem zbiorów bibliotecznych, działalnością apostolską oraz ewentualnymi stowarzyszeniami, komisjami, instytutami, itp." " Należy jednak dodać, że choć ekonom działa pod zwierzchnictwem przełożonego, ale nie jest on jedynie jego delegatem, czy mechanicznym wykonawcą de-

\footnotetext{
${ }^{45}$ Por. E. Gambari, Życie zakonne po Soborze Watykańskim II, s. 375.

${ }^{46}$ KPK 1983, kan. 636 §2. „Klasztory niezależne, o których w kan. 615, powinny raz w roku składać sprawozdania z zarządu ordynariuszowi miejsca. Ponadto ordynariuszowi miejsca przysługuje prawo wglądu w sprawy gospodarcze domu zakonnego na prawie diecezjalnym”, tamże, kan. 637.

${ }^{47}$ B. W. Zubert, Komentarz do Kodeksu Prawa Kanonicznego, s. 103. Sprawozdawczość jest działaniem następczym; do uprzednich należy przygotowywanie projektowanych przychodów i wydatków, co także należy do zadań zarządców, por. KPK 1983, kan. 1284 § 3. Prawo partykularne może stanowić o sprawozdaniach, które przedstawia się wiernym, z dóbr ofiarowanych na potrzeby Kościoła, por. tamże, kan. $1287 \S 2$.
} 
cyzji zwierzchnika. Ekonom posiada swój urząd i związane z tym prawa oraz obowiązki ${ }^{48}$.

2.2. Administracja nadzwyczajna, alienacja, długi i zobowiązania

Zarząd dobrami doczesnymi instytutu zakonnego obejmuje zwyczajną administrację, jak również czynności administracji nadzwyczajnej. Chodzi o czynności przekraczające zwykły zakres obowiązków ekonomów i w niektórych sytuacjach zakres uprawnień przełożonych. W administracji dobrami materialnymi ogólnie rozróżnia się akty: zwykłej administracji lub inaczej mniejszej wagi, większej wagi, nadzwyczajne oraz alienację ${ }^{49}$. Te pierwsze ekonom lub przełożony podejmują swobodnie, z zachowaniem zasady roztropnego zarządzania. Osoby odpowiedzialne za te czynności administracyjne dokonują ich, respektując zasadę zachowania patrymonium kościelnego oraz zwykłe użytkowanie dóbr. Są to czynności regularne, okresowe, powiązane ze zwyczajnymi warunkami życia, pracy, posługiwania instytutu, poszczególnych wspólnot i zakonników, takich jak: utrzymanie, praca, studia, podróże, itp. Zwyczajna administracja nie domaga się dodatkowych pozwoleń czy formalności.

Drugą grupą czynności administracyjnych są akty większej wagi, praktyczne ich wydzielenie jest trudne. Częściowym punktem odniesienia jest stan gospodarczy zakonnej osoby prawnej: dobry lub zły, rząd średnich wydatków w skali miesiąca i roku, oszczędności lub ich brak, itd. Takie i inne dane mogą być subiektywnie interpretowane, a nawet manipulowane. Dlatego wydzielenie aktów administracyjnych większej wagi powinny określać statuty osób prawnych lub prawo własne instytutu. Również wyróżnienie następnej grupy aktów administracyjnych rodzi znaki zapytania, jak oddzielić akty większej wagi

${ }^{48}$ Por. E. Gambari, Życie zakonne po Soborze Watykańskim II, s. 682; V. MoscA, Povertà e amministrazione dei beni negli Istituti religiosi, s. 244-245.

${ }^{49}$ Por. W. Wójcik, J. Krukowski, F. Lempa, Komentarz do Kodeksu Prawa Kanonicznego, s. 73; B. W. Zubert, Komentarz do Kodeksu Prawa Kanonicznego, s. 105; Kodeks Prawa Kanonicznego. Komentarz, red. P. MaJer, Kraków 2011, s. 952. 
od aktów nadzwyczajnych ${ }^{50}$ ? Zapisy na ten temat powinno zawierać prawo własne ${ }^{51}$ oraz zatwierdzone decyzje dla niższego szczebla, np. kapituł prowincjalnych. Jak również należy wziąć pod uwagę analogiczne rozwiązania Kościołów partykularnych, gdzie znajduje się dom lub prowincja zakonna. Częstym punktem odniesienia, by wydzielić akty większej wagi, może być preliminarz budżetowy. Wydatki nie ujęte w nim przekraczają zwykłą administrację. Takimi aktami będzie ponadto obciążenie dóbr zakonnych kredytami albo częściowa sprzedaż. Aktami nadzwyczajnymi będzie alienacja dóbr, kontrakty, które znaczenie pogorszą sytuację materialną osoby prawnej, spory prawne oraz przyjęcie darowizn ze znacznym obciążeniem, lokata pieniędzy ${ }^{52}$. Przy aktach nadzwyczajnych należy spełnić warunki określone prawem. Chodzi o warunki, które wpływają na ważność tych czynności, ale także ich godziwość.

Ważność poszczególnych aktów zależy m.in. od zagadnienia kompetencji. Akty zarządu podejmują ekonomowie, już wyżej omówieni, w ramach swoich kompetencji. Władzę zwyczajną wykonują również ich przełożeni, także w ramach swoich kompetencji oraz osoby delegowane przez przełożonego ad actum. ,Wydatki i akty prawne związane z wykonywaniem zwyczajnego zarządzania, oprócz przełożonych ważnie podejmują, w ramach powierzonej im funkcji, także urzędnicy, których własne prawo do tego celu wyznacza" 53 .

${ }^{50}$ Dla Kościołów partykularnych punktem odniesienia dla wyróżnienia aktów nadzwyczajnej administracji są ewentualne decyzje Konferencji Episkopatu, por. KPK 1983, kan. 1277.

${ }^{51}$ „Własne prawo w ramach prawa powszechnego, winno określić akty, które przekraczają cel i sposób zwyczajnego zarządzania oraz sprecyzować warunki konieczne do ważnego podjęcia nadzwyczajnego aktu administracyjnego", tamże, kan. $638 \S 1$.

${ }^{52}$ Por. tamże, kan. 1291, 1295, 1288, 1267 §2; A. Chrapkowski, J. KrzywdA, J. WroCEŃSKI, B. W. ZuBert, Komentarz do Kodeksu Prawa Kanonicznego, s. 70-71; B. W. ZuBert, Komentarz do Kodeksu Prawa Kanonicznego, s. 105-108; J. R. BAR, J. KaŁowsKi, Prawo o instytutach, s. 92-93; A. CALABRESE, Istituti di vita consacrata e società di vita apostolica, Città del Vaticano 2010, s. 164-167.

${ }^{53}$ KPK 1983, kan. 638 §2. Por. B. W. Zubert, Komentarz do Kodeksu Prawa Kanonicznego, s. 105-106. 
Do czynności nadzwyczajnego zarządu należy przede wszystkim alienacja dóbr doczesnych. Zakres tego pojęcia, warunki wymagane do ważności oraz godziwości określa prawo powszechne Kościoła w księdze piątej Kodeksu z 1983 r. ${ }^{54}$ Ponadto dodatkową normę na ten temat zawiera księga druga prawa kodeksowego: „Do ważności alienacji i jakiegokolwiek działania, przez które stan majątkowy osoby prawnej może doznać uszczerbku, potrzebne jest pisemne zezwolenie kompetentnego przełożonego, wydane za zgodą jego rady. Jeśli natomiast chodzi o transakcje, w których suma przekracza wysokość określoną dla danego regionu przez Stolicę Apostolską, albo przedmiotem są dobra ofiarowane Kościołowi na mocy ślubu albo rzeczy drogocenne z racji artystycznych lub historycznych, potrzebna jest ponadto zgoda Stolicy Świętej" 55 .

Alienacja występowała w prawie rzymskim majątkowym. Rozróżnia się dwa znaczenia alienacji: w znaczeniu ścisłym i szerokim. Wąsko rozumiana jest przeniesieniem prawa własności z jednego podmiotu na drugi (sprzedaż), z tytułem darmowym (darowizna) albo obciążającym (zamiana). W szerszym ujęciu alienacją będzie przeniesienie jakiegokolwiek prawa majątkowego, które powoduje znaczne pogorszenie stanu posiadania kościelnej osoby prawnej (np. dzierżawa, zastaw, hipoteka, pożyczka). Pogorszenie stanu posiadania następuje przez zmniejszenie realnej wartości majątku albo przez przyjęcie zobowiązań, które dla osoby prawnej są znaczące. Tradycja prawa kanonicznego, następnie Kodeks Prawa Kanonicznego z 1917 r. oraz ak-

${ }^{54}$ Por. KPK 1983, kan. 1291-1296; E. SzTAFrowsKi, Podręcznik prawa kanonicznego, t. 4, Warszawa 1986, s. 293-296; T. PAwluK, Prawo kanoniczne wedtug Kodeksu Jana Pawła II. Dobra doczesne Kościoła Sankcje w Kościele Procesy, t. 4, Olsztyn 1990, s. 50-53; W. Wóscik, J. Krukowski, F. Lempa, Komentarz do Kodeksu Prawa Kanonicznego, s. 86-92; L. ŚwITo, Alienacja majątku kościelnego w diecezjach rzymskokatolickich $w$ Polsce, Olsztyn 2010, s. 89-213.

${ }^{55}$ KPK 1983, kan. 638 §3. Do ważnej alienacji dla klasztorów niezależnych oraz instytutów na prawie diecezjalnym, konieczna jest ponadto pisemna zgoda ordynariusza miejsca, por. tamże, kan. 638 §4. Por. także Congregazione PER GLI Istituti di Vita Consacrata e le Societa di Vita Apostolica, Lettera Già da alcuni decenni (Amministrazione dei beni temporali negli istituti religiosi), 21.12.2004, Enchiridion Vaticanum XXII, nr 3286-3295, s. 1954-1957. 
tualnie obowiązujący Kodeks Prawa Kanonicznego z 1983 r. wskazują na szeroko rozumianą alienację i w tym znaczeniu obowiązują ustanowione normy. To szersze rozumienie alienacji należy odnieść do czynności administracyjnych, które dotyczą zakonnych dóbr doczesnych.

Normy na temat alienacji dotyczą tych dóbr zakonnych, które należą do określonej osoby prawnej i te, które stanowią zarazem stały majątek tej osoby (patrymonium kościelne). Podstawowym wymogiem do ważności czynności jest uzyskanie pisemnego zezwolenia odpowiedniego przełożonego, którego wskazuje prawo własne. Także sposób uzyskania zgody swojej rady przez przełożonego winno określić prawo własne instytutu (jednomyślność czy większość w głosowaniu, decyzja kolegialna czy niekolegialna, głosowanie tajne czy jawne, itd.) ${ }^{56}$.

W niektórych sytuacjach do ważności alienacji konieczna jest ponadto zgoda Stolicy Apostolskiej, tj. gdy transakcje przekraczają wysokość określoną dla danego regionu przez tę Stolicę (Kongregację Instytutów Życia Konsekrowanego i Stowarzyszeń Życia Apostolskiego). Jeśli Stolica Apostolska nie określi takiej sumy dla instytutów zakonnych w określonym regionie, to punktem odniesienia staje się suma ustanowiona przez Konferencję Episkopatu ${ }^{57}$. Wyróżnienie czynności administracji poniżej kwoty maksymalnej oraz odpowiednich przełożonych, którzy są kompetentni do wydania zezwolenia na alienację, także określa prawo własne instytutu.

Analogicznie do kan. 1292, również kan. 638 domaga się zgody Stolicy Apostolskiej na alienację dóbr ofiarowanych Kościołowi na mocy ślubu albo rzeczy drogocennych z racji artystycznych lub histo-

${ }^{56}$ Przed podjęciem decyzji, przełożony oraz radcy powinni zapoznać się z wyceną rzeczy alienowanej, już dokonanymi alienacjami, stanem materialnym osoby prawnej, opinią lub zgodą innych zainteresowanych osób, por. tamże, kan. 1292 §3-4, 12931295.

${ }^{57}$ Por. E. Gambari, Życie zakonne po Soborze Watykańskim II, s. 683. Aktualnie odpowiednie kwoty w Polsce są ustalone na następujących progach: 100.000,00 Euro - suma najniższa, 1 milion Euro - suma najwyższa, por. Dekret Kongregacı DS. BISKUPÓw z 05.12.2006 r. zawierający recognitio decyzji Konferencji Episkopatu Polski w sprawie sum (minimalnej i maksymalnej), w związku z alienacją dóbr kościelnych, Prot. N 901/84; Akta Konferencji Episkopatu Polski 13 (2007), s. 32-33. 
rycznych. Zasadniczo dary wotywne nie podlegają alienacji. W wyjaśnieniu tego, czym są dary wotywne sięgnąć należy do wypowiedzi Kongregacji Soboru z dnia 14 stycznia 1921 r., u której orzekła ona, że o ile nie występują inne przesłanki, przedmioty złożone na ołtarzu lub ze względu na jakiś święty obraz, są darami ex voto ${ }^{58}$. Alienacja tego rodzaju dóbr wotywnych domaga się zgody Stolicy Apostolskiej. Dodatkowo w takim przypadku wymaga się, aby przy prośbie o alienację rzeczy wotywnych i drogocennych przedstawić opinię komisji sztuki sakralnej i liturgicznej oraz biegłych rzeczoznawców ${ }^{59}$. Wartość rzeczy drogocennych z racji artystycznych lub historycznych nie wynika z użycia cennego materiału (złoto, srebro, platyna, itp.), z którego je wykonano, choć to także należy uwzględnić. Wymagane zezwolenie Stolicy Apostolskiej w odniesieniu do rzeczy ofiarowanej z racji ślubu, walorów historycznych czy artystycznych, dotyczy także tych dóbr, których wycena nie przekracza najwyższej sumy określonej przez Stolicę Apostolską ${ }^{60}$.

W administracji dobrami zakonnymi równie ważna jak alienacja jest sprawa odpowiedzialności za długi i zobowiązania. „Jeśli osoba prawna zaciągnęła długi i zobowiązania, nawet za zezwoleniem przełożonych, sama powinna za nie odpowiadać"61. Czynność prawna tego rodzaju domaga się zgody kompetentnego przełożonego. Osoba praw-

58 "IV. Utrum mera oblatio doni ad altare vel ad sacram iconem, praesumptionem voti secum ferat, an positive constare debeat donariumex voto oblatum esse. (...) Ad 4. Donarium praesumi votivum nisi de contraria donatoris vel offerentis voluntate aliunde constet.", Sacra Congregatio Concilii, Circa donaria votiva et alienationes, 14.01.1922, AAS 14(1922), s. 160-161.

${ }^{59}$ Por. Sacra Congregatio Pro Clericis, Litterae circulares De cura patrimonii historico-artistici Ecclesiae, ad Praesides Conferentiarum Episcopalium, 11.04.1971, AAS 63(1971), s. 315-317; Kodeks Prawa Kanonicznego. Komentarz, red. P. MaJER, S. 966.

${ }^{60}$ Prawo powszechne Kościoła stanowi ponadto, że obrazy oraz relikwie doznające w jakimś kościele wielkiej czci od wiernych, nie mogą być w jakikolwiek sposób alienowane ani też na stałe przenoszone bez zezwolenia Stolicy Apostolskiej; nie jest też godziwym działaniem sprzedaż relikwii, por. KPK 1983, kan. 1190 §1-3. Bezprawna alienacja może skutkować sankcją karną: „Kto alienuje dobra kościelne bez przepisanego prawem zezwolenia, powinien być ukarany sprawiedliwą karą.”, tamże, kan. 1377.

${ }^{61}$ Tamże, kan. $639 \S 1$. 
na, reprezentowana przez przełożonego zakonnego, czy w ramach kompetencji przez ekonoma tej osoby prawnej, odpowiada za długi i zobowiązania z posiadanych dóbr i zasobów. Dokładniej, odpowiada ta konkretna osoba prawna, która zaciągnęła zobowiązania, np. dom zakonny lub prowincja, a nie cały instytut. W prawie polskim przyjęto zasadę, że odpowiedzialności jednej osoby prawnej kościelnej nie przenosi się na inną taką osobę: ,kościelna osoba prawna nie odpowiada za zobowiązania innej kościelnej osoby prawnej"62.

Gdyby długi zaciągnął zakonnik, jako osoba fizyczna, wówczas on sam odpowiada za nie, nawet posiadając uprzednią zgodę przełożonego, a tym bardziej gdyby jej nie miał. W wyjątkowej sytuacji, kiedy zakonnik załatwia sprawę na polecenie przełożonego, odpowiedzialnym jest wówczas instytut zakonny. Otrzymując mandat ze strony instytutu (konkretnych przełożonych), załatwia on sprawy zakonne, a nie własne, więc nie on indywidualnie ponosi konsekwencje umowy ${ }^{63}$. Również gdyby działając na polecenie przełożonych, zaciągnął zobowiązania względem własnych dóbr (jeśli takie prawomocnie posiada), gwarantem ich wypełnienia jest instytut ${ }^{64}$.

Celem ochrony instytutu przed niekorzystnymi kontraktami można wnieść skargę przeciw osobom, które odniosły korzyść z zawartej umowy ${ }^{65}$. Zaciągnięcie długów domaga się przemyślanej i rozsądnej decyzji. Przełożeni mogą wydać zgodę na nie, jeśli w niedługim czasie można spłacić zobowiązania ze zwyczajnych dochodów ${ }^{66}$.

${ }^{62}$ Ustawa z dnia 17 maja 1989 r. o stosunku Państwa do Kościoła katolickiego w Rzeczypospolitej Polskiej, Dz. U. z 1989 r. Nr 29, poz. 154 z późn. zm., art. 11.

${ }^{63}$ „Jeśli zaciągnął je członek instytutu za zezwoleniem przełożonego w stosunku do swoich dóbr, sam jest odpowiedzialny, jeśli zaś na polecenie przełożonego załatwił sprawę instytutu, odpowiedzialny jest instytut. Jeśli zaciągną je zakonnik bez zezwolenia przełożonych, powinien odpowiadać sam, a nie osoba prawna”, KPK 1983, kan. 639 §2-3.

${ }^{64}$ Por. B. W. Zubert, Komentarz do Kodeksu Prawa Kanonicznego, s. 109. Niekiedy pojawi się sytuacja, którą można zinterpretować, jako milczące lub domniemane pozwolenie przełożonego, co pociąga odpowiedzialność instytutu, por. E. GAMBARI, Życie zakonne po Soborze Watykańskim II, s. 678.

${ }^{65}$ „Zawsze jednak można wnieść skargę przeciw temu, który odniósł jakąś korzyść z zawartego kontraktu”, KPK 1983, kan. 639 §4.

${ }^{66}$ „Przełożeni zakonni nie powinni zezwalać na zaciąganie długów, jeśli nie jest 


\section{Dobra kościelne}

Czym są dobra kościelne? Prawo powszechne ujmuje tę kwestię następująco: „Wszystkie dobra doczesne, należące do Kościoła powszechnego, do Stolicy Apostolskiej lub do innych publicznych osób prawnych w Kościele, są dobrami kościelnymi i rządzą się kanonami, które następują, oraz własnymi statutami"'67.

W komentarzach prawa kanonicznego tak wydzielone dobra doczesne nazywa się też dobrami kościelnymi w znaczeniu ścisłym ${ }^{68}$. Należy podkreślić, że chodzi o własność przynależącą do publicznych osób prawnych kościelnych. Kanoniczny podział na publiczne i prywatne osoby prawne ma swoje zastosowanie, m.in. w księdze piątej obowiązującego Kodeksu Prawa Kanonicznego ${ }^{69}$. Oznacza to, że te pierwsze osoby mogą nabywać, posiadać, zarządzać i alienować dobra w imieniu Kościoła, zgodnie z brzmieniem kanonów: 116 i 1254.

W odróżnieniu od dóbr publicznych osób prawnych, inaczej sytuują się środki materialne, które przynależą do prywatnej osoby prawnej. Zarząd dobrami osoby prywatnej jest regulowany przede wszystkim własnymi statutami, nie natomiast prawem powszechnym Kościoła, tj. głównie normami piątej księgi Kodeksu z 1983 r. ${ }^{70}$ Podział na osoby prawne publiczne i prywatne i w konsekwencji rozróżnienie dóbr ko-

pewne, że ze zwyczajnych dochodów można spłacić należne procenty, oraz w niezbyt długim czasie z uzyskanej zgodnie z prawem amortyzacji zwrócić sumę podstawową", tamże, kan. 639 §5.

${ }^{67}$ Tamże, kan. 1257 § 1. „Dobra doczesne instytutów zakonnych jako kościelne rządzą się przepisami księgi V Dobra doczesne Kościoła, chyba że co innego wyraźnie zastrzeżono", tamże, kan. 635 §1. Por. V. MoscA, Povertà e amministrazione dei beni negli Istituti religiosi, s. 242-243; A. PerLasca, La capacità patrimoniale degli istituti religiosi, Quaderni di Diritto Ecclesiale 22(2009), s. 124-125; Y. Sugawara, Le norme sui beni temporali negli istituti religiosi (can. 635), s. 414-415; V. MoscA, Il ruolo della gerarchia nell'amministrazione comunionale dei beni della Chiesa, w: Iustitia in caritate, Miscellanea di studi in onore di Velasio de Paolis, Città del Vaticano 2005, s. 390-393.

${ }^{68}$ Por. W. Wóscik, J. Krukowski, F. Lempa, Komentarz do Kodeksu Prawa Kanonicznego, s. 50.

${ }^{69}$ Rozróżnienie osób prawnych na publiczne i prywatne, por. KPK 1983, kan. 116.

${ }^{70}$ „Dobra doczesne prywatnej osoby prawnej rządzą się własnymi statutami a nie tymi kanonami, chyba że wyraźnie jest inaczej zastrzeżone", tamże, kan. 1257 §. 
ścielnych od „niekościelnych” był szeroko dyskutowany przy redagowaniu norm aktualnego Kodeksu ${ }^{71}$. Majątek osób prawnych prywatnych, które zgodnie z zapisem kan. 116 Kodeksu z 1983 r. nie występują w imieniu Kościoła, zależy przede wszystkim od norm prawa cywilnego oraz własnych statutów ${ }^{72}$. „Podkreślenie, że osoby prawa prywatnego rządzą się własnymi statutami, a w wyjątkowych wypadkach prawem powszechnym, nie wyklucza ściśle biorąc ani prawa partykularnego, ani nadzoru biskupa, ani kościelnego charakteru mienia tych osób"73. Odniesienie do nadzoru biskupa lub innego ordynariusza personalnego ma swoje znaczenie przez to, że mogą istnieć liczne osoby prawne prywatne powiązane $\mathrm{z}$ instytutami zakonnymi, np. tzw. trzecie zakony, stowarzyszenia i fundacje.

Omawiając zagadnienie dóbr doczesnych, można ponadto zauważyć, że brakuje ustawowego ich zdefiniowania. W Kodeksie Prawa Kanonicznego z 1917 r. ustawodawca precyzował pojęcie dóbr, wymieniając pośród nich: dobra nieruchome i ruchome, cielesne i niecielesne, rzeczy święte (bona sacra) oraz drogocenne (bona pretiosa) ${ }^{74}$. Takiego wyliczenia aktualny Kodeks z 1983 r. nie podaje, choć prawo-

${ }^{71}$ Por. W. Wójcik, J. Krukowski, F. Lempa, Komentarz do Kodeksu Prawa Kanonicznego, s. 51-52.

${ }^{72}$ Niekiedy majątek osób prawnych prywatnych postrzega się, jako dobra kościelne w szerokim ich ujęciu. Argumentem za taką interpretacją byłaby np. aprobata dla zaistnienia kościelnych osób prawnych prywatnych, co także ma swoje znaczenie w kwestiach majątkowych, choćby przez nadzór kościelny nad nimi, czy obowiązek składania sprawozdań kompetentnej władzy kościelnej, por. KPK 1983, kan. 322-323, 325.

${ }^{73}$ W. Wóscik, J. Krukowski, F. Lempa, Komentarz do Kodeksu Prawa Kanonicznego, s. 52. Z drugiej strony istnieją opinie nazywające wprost dobra osób prywatnych świeckimi: „Z zestawienia obu kanonów wynika, że prywatne osoby prawne cieszą się ową zdolnością kanoniczną, niemniej jednak należące do nich dobra - chociaż stanowią własność osób prawnych Kościoła (w tym przypadku prywatnych) i służą celom kościelnym - nie są kościelne, lecz świeckie.”, Kodeks Prawa Kanonicznego. Komentarz, red. P. MAJER, s. 933. Por. też dyskusję nad problemem: S. DubIEL, Uprawnienia majątkowe Kościoła Katolickiego w Polsce w świetle Kodeksu Prawa Kanonicznego z 1983 r., Konkordatu z 1993 r. i ustaw synodalnych, Lublin 2007, s. 31-32; V. DE PAoLIs, I beni temporali della Chiesa, Bologna 2001, s. 11-16.

${ }^{74}$ Por. Codex Iuris Canonici, Pii X Pontificis Maximi iussu digestus, Benedicti Papae XV auctoritate promulgatus, Typis Polyglottis Vaticanis 1956, can. 1497. 
dawca kościelny używa w tym zbiorze prawnym terminów: dobra ruchome i nieruchome, bona sacra i bona pretiosa ${ }^{75}$. Aktualną interpretację pojęć dóbr ruchomych i nieruchomych należy odnieść do norm prawa cywilnego.

Powracając do instytutów zakonnych, w opracowaniu poniższym już stwierdzono, że te instytuty są osobami prawnymi publicznymi. Ponadto, zgodnie z kan. 635 dobra doczesne instytutów zakonnych kwalifikuje się jako kościelne i rządzą się one przepisami księgi piątej Kodeksu z 1983 r. oraz prawem własnym. W tym miejscu trzeba powrócić do pytania postawionego na początku, jaka jest relacja ślubu ubóstwa do dóbr kościelnych, w jego wspólnotowym ujęciu.

\section{Podsumowanie: instytut a dobra kościelne}

Dokumenty Magisterium Kościoła oraz normy prawa kanonicznego wymagają od instytutów zakonnych zbiorowego świadectwa ubóstwa. Ubóstwo to ma służebny charakter, tj. dobra kościelne są wprzęgnięte w potrzeby Kościoła i pomoc ubogim, lub inaczej powinny one służyć celom Kościoła. Tak ogólnie określone zadania precyzować powinno prawo własne instytutu, jak również konkretne działania praktyczne i czynności prawne podejmowane przez osoby odpowiedzialne za dobra zakonne.

Dobra już posiadane przez konkretny instytut wymagają następnie dobrego zarządu. Zwykle administracja dobrami kościelnymi należy do ekonomów zakonnych, którzy działają pod zwierzchnictwem swoich przełożonych. Decyzje ekonomów i przełożonych, czy ewentualnie innych uprawnionych osób, winno cechować wysokie poczucie odpowiedzialności. Nie są to dobra osób fizycznych, czy dobra prywatne, ale należące do publicznej osoby prawnej. A ta z kolei działa w imieniu Kościoła. Ze względu na autorytet Kościoła, zarząd dobrami zakonnymi domaga się nie tylko uważnego stosowania norm prawnych, kano-

${ }^{75}$ Rzeczy ruchome i nieruchome, por. KPK 1983, kan. 1270, 1283 n. 2, 1285, 1302 $\S 1,1305,1376$; rzeczy święte, por. tamże, kan. 1171, 1212, 1269, 1376; rzeczy kosztowne, por. tamże, kan. 1270. 
nicznych i cywilnych, ale także nauki społecznej Kościoła, jak również w najwyższym stopniu wymaga respektowania zasad moralnych ${ }^{76}$.

Wskazania powyższe odnieść trzeba tak do zarządu zwyczajnego, jak i nadzwyczajnego. Czynności zarządu o większym znaczeniu ekonomicznym, akty nadzwyczajne, zobowiązania i długi, w sposób ramowy reguluje prawo powszechne Kościoła. A bardziej szczegółowe zapisy zawiera prawo własne instytutu. Respektowanie tych norm wpływa na ważność i godziwość poszczególnych czynności zarządu dobrami kościelnymi, tak na forum kanonicznym, jak i w przestrzeni prawa cywilnego.

Zobowiązania i długi, które zaciąga zakonna osoba prawna, są spłacane z posiadanych przez instytut dóbr kościelnych. W wyjątkowej sytuacji, poszczególny zakonnik, niebędący ekonomem czy przełożonym, załatwia sprawę na polecenie przełożonego. Także wówczas instytut odpowiada za zobowiązania lub długi z posiadanych dóbr zakonnych. Dotyczy to również sytuacji, gdyby działając na polecenie przełożonych, zakonnik zaciągnął zobowiązania względem jego prywatnych dóbr.

We współczesnej sytuacji instytuty w różny sposób nabywają dobra doczesne. W zakres dóbr wspólnych wchodzą także te, które zakonnicy nabywają lub wypracowują indywidualnie, ale ze względu na instytut: „cokolwiek nabywa zakonnik - nabywa klasztor"77. Dotyczy to także środków przysługujących z tytułu pracy, pensji, zapomogi albo ubezpieczenia. Nabywa je instytut - za pośrednictwem swoich członków - i wchodzą one w całokształt posiadanych przezeń dóbr kościelnych.

Instytuty zakonne będąc osobami prawnymi publicznymi, posiadają prawo nabywania, posiadania, zarządzania i alienowania dóbr kościelnych. Wszelkie działania w tych zakresach: instytutów i ich reprezentantów powinny wyrażać świadectwo wiary, ubóstwa oraz zaufania złożonego w Bogu. Wspólnotowe świadectwo o ślubie ubóstwa ukazuje jego duchowy wymiar. Stanowi to także istotny komunikat dla

${ }^{76}$ Por. II Polski Synod Plenarny (1991-1999), Poznań 2001, s. 79, nr 54-55.

${ }^{77}$ B. W. Zubert, Komentarz do Kodeksu Prawa Kanonicznego, s. 172; por. J. R. BAR, J. KaŁowsKi, Prawo o instytutach, s. 134-137, 139-142. 
współczesnego świata o potrzebie i możliwości zdrowego dystansu do kwestii posiadania dóbr materialnych.

\section{Poverty of religious institute in relation to the issue of Church goods}

Religious institutes are a special sign of faith for the whole world. This includes public testimony of religious gave to Christ and the Church. Poverty in religious institutes has an individual dimension, but also common one. This paper discusses the communal aspects of vow of poverty, confronted with the concept of Church goods.

Religious goods require good management. The decisions of the stewards and the superiors, or other eligible persons should be greatly responsible. Above mentioned goods belong not to natural persons, nor to private persons, but to a public legal person, which acts on behalf of the Church. Due to the authority of the Church, a board of directors managing religious goods demands not only a careful applying legal norms, canonical and civil, but also the social doctrine of the Church and respecting moral principles.

These recommendations should apply to both, the ordinary board and extraordinary, as well as to the financial obligations and debts. The scope of the commons goods includes also those the goods, which are acquired by religious for the institute's use: "whatever acquires religious - acquires monastery". This also concerns means resulting from employment, wages, allowances, or insurance.

Since religious institutes are a public legal persons, they have the right to acquire, hold, manage and alienate Church goods. All activities taken by the institutes and their representatives in that scope should express a testimony of faith. A communal testimony on the vow of poverty shows its spiritual dimension. This constitutes an important message for the modern world showing the need and ability to maintain detachment from the possession of material goods. (tłum. M. Zawistowska) 